\title{
Environmental disclosure practices after mandatory disclosure policy in Indonesia
}

\author{
Rizal Yaya \\ Sigit Arie Wibowo \\ Ulfaturrahmah \\ Universitas Muhammadiyah Yogyakarta, Indonesia \\ Dayana Jalaludin \\ Universiti Sains Malaysia, Malaysia
}

\begin{abstract}
Keywords
Environmental disclosure, mandatory disclosure, legitimacy theory, Indonesia
\end{abstract}

\begin{abstract}
This study examines the effect of new mandatory disclosure policy, Government Regulation no 47/2012, on Indonesian environmental disclosure practices. The sample consists of 249 companies listed in Indonesia Stock Exchange from all industries except trading and financial sectors. Tha data is based on annual reports and sustainability reports from 2011 to 2013 which were available in the public domain. Year 2011 was the year before the policy was issued, 2012 was the issuance year, and 2013 was the year after the issuance. Comparing environmental disclosure practices at the year before and the year of the mandatory policy being issued, there were significant increases in terms of GRI index based information being reported; the number of words used to report environmental issues based on GRI; carbon emission index being reported; and the number of words used to report carbon emission aspects. In year 2011, only 13.95\% companies were disclosing based on GRI, but then the amount increased to become $25.25 \%$ in 2012 and $30.90 \%$ in 2013. Based on detail analysis, it was found that the significant increases occur not in the companies with high carbon emission, but in the companies with moderate or low carbon emission. This study supports legitimacy theory as described by Suchman (1995) where in order to gain legitimacy, the role of social audience in legitimacy dynamics should be addressed. In this case, the issuance of new mandatory regulation has increased participation of moderate and low carbon emission companies in environmental disclosure practices where previously the issues used to be of interest for companies with high carbon emission only.
\end{abstract}

Corresponding author: Rizal Yaya

Email addresses for corresponding author: r.yaya@umy.ac.id

First submission received: $19^{\text {th }}$ October 2017

Revised submission received: $10^{\text {th }}$ December 2017

Accepted: 28 $8^{\text {th }}$ December 2017

Introduction

Prior research on environmental disclosure had been focusing on voluntary disclosures (Deegan and Rankin, 1996; Nik Nazli and Maliah 2004; Clarkson et al, 2008) leaving many unanswered questions particularly as to how it would bring about better environmental performance. Voluntary environmental disclosure, despite its merit as a starting point in fostering proactive sustainable business activities, has been criticised due to its limitations in ensuring that information reported are genuine and of good quality (Tilt 1994, Newton and Harte 1997). On the other hand, mandatory environmental disclosure policy, which functions as both tools of inducement and enforcement, is claimed as a better communication platform which would provide the much needed push for businesses to go beyond greenwashing (Mobus, 2005). This is due to the fact that mandatory disclosure directly exposes business organisations toward public scrutiny thus engendering them to seriously consider the link between their activities and the environment. Mandatory disclosure constitutes the 'compliance' factor which requires corporate responsibility approaches to be conducted more consistently and involved internalization of environmental costs, in order to reduce externalities.

The Indonesian government has taken several steps to reduce pollution in the country. Early initiative was in 1990 organised by the Ministry of Environment to reduce pollution in river. Due to weak 
law enforcement system, since 1995 the program was then designed into the form of assessing and publishing companies waste water performance. Then, since 2002, the assessment was developed to include all three medium: water, air and soil, where in 2010 there had been 1,000 companies participated voluntarily to be assessed, classified and published to the public about their environmental achievements. Effort in terms of establishing adequate law had taken place in 2001 when Act no 22 on Oil and Gas was issued. The Act requires companies in oil and gas industry to prevent and manage pollution and recover any environmental damage including post-mining operation. To extend the coverage of environmental regulation, in 2007, the Government issued a new Limited Company Act known as UU no. 40 year 2007, which requires any company which uses natural resources eg mining or any company which does not directly use natural resources but their operation have effects on environment, to undertake social and environmental responsibility activities. A further step was when the Government issued Act no 32 year 2009 on Environmental Protection and Management, which says anyone or any entity which causes ambient quality for air, water, seawater, or environmental damage exceeds the standards, will have certain range of number of years in jail or certain amount of penalty based on their intention and degree of effects on people.

Later, in 2012, the Indonesian Government issued a Government Regulation, Peraturan Pemerintah (PP) no. 47/2012 on social and environmental responsibility. This Government Regulation is the first that requires companies to report their social and environment activities in their annual report. The government, in its introduction to the PP 47 year 2012, said that the regulation is a follow up to the Limited Company Act 40/2007 as it would strengthened the country's corporate social responsibility (CSR) agenda. The introduction of the regulation is timely given the fact that the business industries have been identified as one of the biggest contributor of carbon emission in the world (Pricewaterhouse Coopers, 2013). Furthermore, the level and quantity of corporate responsibility reports in Indonesia were relatively low during that time, raising many questions on the role of businesses particularly regarding their responsibility towards the society (Utama, 2011). Following the issuance of the new regulation, companies in Indonesia are now required not only to undertake social and environmental activities (as stipulated by the limited Company Act 40/2007), but they are also obliged to disclose their social and environmental activities in their annual report.

Nevertheless, not much is known about the impact of the abovementioned change in regulation context, particularly on the outcome in terms of environmental performance. Considering this gap, the present study attempts to provide a baseline picture of changes that have happened in Indonesia, particularly in terms of environmental disclosure. Such exposure would be an important starting point for policy makers in drawing out future control measures for different type of industries in Indonesia.

Across the globe, study on the impact of mandatory policy related to environmental disclosures practices had been discussed from various perspectives such as environmental regulatory performance (Mobus, 2005), volume and quality of disclosures (Jiménez et al. 2008; Choi et al. 2013; Kuo and Chen 2013; Chelli et al. 2014; Zheng et al. 2014), strategy and image (Kuo and Chen 2013), and relationship with shareholders (Zheng et al. 2014). Drawing from legitimacy theory, this study extends present literature by exploring legitimacy issue instigated by a mandatory regulation towards different types of industries with different nature of activities. As companies under different phases or needs for legitimacy will have different effort in convincing their social audience (Suchman, 1995), a closer look at the degree of environmental disclosure among the different industries would provide some guidance for policy makers in terms of establishing future minimum requirements regarding the nature and content of environmental disclosure.

\section{Literature review}

Legitimacy theory has been popularly used in environmental disclosure studies (Suchman, 1995; Gray et al., 1995; Deegan, 2002) given the fact that disclosure practice is a response to economic, social and political pressures surrounding companies in their effort to legitimise corporate existence and behaviours (Guthrie and Parker 1989). It is important to note that the legitimation dynamics go beyond the incorporation of evaluative and cognitive aspects, as they also acknowledge the role of social audience (Suchman, 1995). Thus, legitimacy may be defined as 'a generalized perception or assumption that the actions of an entity are desirable, proper, or appropriate within some socially constructed system of 
norms, values, beliefs, and definitions (Suchman, 1995, p. 574)'. Central to the legitimacy theory is the social contract concept which underlines that a social contract exists between organisations and individual society members (Choi et al. 2013, p.63). The society offers organisations legal rights and authority to access natural and human resources that they need for their operations. On the other hand, the organizations, in exchange for the access of resources, 'must continuously seek to comply' with the community expectations to ensure their operations 'remain legitimate' (Mathews, 1993).

Generally, literature on legitimacy can be classified into three broad types i.e. pragmatic legitimacy, moral legitimacy and cognitive legitimacy (Suchman, 1995). Pragmatic legitimacy is about doing self interest calculations based on most immediate audiences, where the motivation is to meet the requirement of the evaluator in direct exchange for sustenance. This type of legitimacy happens when a behavior is undertaken by the organization mainly to gain support for a certain organisational policy from a certain constituent, for instance, by incorporating or adopting the constituents' standards of performance as its own. A common indicator of pragmatic legitimacy is the organisation's adoption of the authority's policy. Responding through pragmatic legitimacy is often claimed to be more important and easy as compared to producing immediate results (Meyer and Rowan, 1991).

The second type of legitimacy, i.e. moral legitimacy is rationalized from judgments about doing the right thing. Moral legitimacy is based upon beliefs on whether the activity would effectively promote societal welfare. Among the forms of moral legitimacy are evaluations of outputs and consequences; evaluations of techniques and procedure; evaluation of categories and structures; and evaluation of leaders and representatives (Suchman 1995, p. 579). The third type of legitimacy is labelled by Suchman (1995) as the most powerful source of legitimacy. This type of legitimacy goes beyond interest or evaluation, where the doing is moved by cognition, either as comprehension or taken for granted. Under this legitimacy, as the social structure has been cosntrued, things to be otherwise is literally unthinkable. For example, non-surgical treatment of acute appendicities is unthinkable by the society, but patients and malpractice attorneys routinely challenge the legitimacy and competence of surgeons and hospitals ( $p$. $583)$.

Effort for legitimacy can be distinguished into two types: either seeking for active support or mere passive acquiescence, depending on the objectives against which these efforts are measured (Suchman, 1995). The legitimacy demand for an organization which seeks active support is very stringent. This is because the organisation requires support in acquiring or enhancing access to needed resources. On the other hand, if the objective of the organization is for a audience not to interfere, the threshold of legitimation is quite low for the organization to exist as unproblematic in the eyes of the society.

The effort for legitimacy would also depend upon the phase when the challenge arises, whether at the phase of gaining legitimacy, maintaining legitimacy or repairing legitimacy (Suchman, 1995). Gaining legitimacy and repairing legitimacy is similar in their dificulties and requires more effort as compared to maintaining legitimacy. Challenges in gaining legitimacy can be in terms of having new operations which are technically problematic and poorly institutionalised such as the establishment of early nuclear power plant, or in terms of being a new entrant in an old sector. In gaining legitimacy, a number of effort should be rendered by an organisation such as effort to conform with prexisting audience within organisation's current environment; effort to select among multiple environment in pursuit of an audience that will support the current practices; and the effort to manipulate environmental structure by creating new audiences and new legitimating beliefs (Suchman. 1995).

Once legitimacy is gained, it would be taken for granted and legitimation activities become 'increasingly routinised' (Ashforth and Gibbs, 1990). During the maintaining phase, organization would focus on recognising audience reactions, forseeing emerging challenges and protecting past accomplishment (Suchman, 1995). Past accomplishments are retained through the policing of internal operations to prevent miscues and develop a defensive stockpile of supportive beliefs, attitudes and accounts. Once credibility is gained, constituents tend to relax their vigilance and contend themselves with evidence of ongoing performance vis a vis their interest and with periodic assurance of business as usual (Ashforth and Gibbs, 1990). Here, the organization will concentrate on avoiding unexpected events which may resuscitate scrutiny (Suchman, 1995). 
Legitimacy is dynamic and subjected to change in time and place (Lindblom, 1993) hence what was perceived acceptable in the past may no longer be legitimate at present. Disparity or legitimacy gap happens when there is a mismatch between public expectations about how organisations should behave and the perception on how organisations do act (Suchman 1995). Greater efforts are needed in the repairing legitimacy phase. Unlike legitimacy creation, legitimacy repair represents a reactive responses to an unforeseen crisis of meaning. At this period familiar legitimacy stategies and claims might not be relevant anymore and may be discredited (Suchman, 1995). Here, different focus will be needed, for instance through strategic restructuring to facilitate legitimation.

The migration from voluntary to mandatory disclosure requirement in Indonesia is a signal that indicates a change in public expectations toward how companies should communicate their environmental related activities. Thus, the present study, through legitimacy theory perspective, espouses the idea that companies will conform to the newly introduced regulation so that they will remain legitimate by improving their volume and quality of reporting. The present study will also go one step further, by examining how the trends of disclosure differ according to sectors, ownership and environmental sensitivity level. Such investigation is vital in providing explanation regarding differences in legitimacy efforts and phases, which mark some hint on whether the change in regulation will subsequently meet its intended outcome for better environmental performance.

Study on mandatory environmental disclosure policy and environmental disclosures had been undertaken in developing (Jiménez et al. 2008, Zheng et al. 2014) and developed countries (Mobus, 2005; Choi et al. 2013; Kuo and Chen, 2013 and Chelli et al. 2014). Some studies examined the effect of the mandatory disclosure policy, while others examined the factors affecting firms in reporting their social and evironmental disclosures. The role of mandatory environmental disclosure as a critical tool of public policy that goes beyond managing society's impressions was highlighted by Mobus (2005) in his investigation on firms in the United States petroleum refining industry between 1992 to 1994 . By looking at the relationship between mandatory disclosures of environmental legal sanctions and subsequent regulatory violations, it was found that environmental disclosures indirectly would bring about better environmental performance. As mandatory disclosures provide a clearer picture of the relevant audience expected outcomes, it gives firms the much needed push to move beyond their symbolic legitimacy zone and improve in terms of environmental performance (Mobus, 2005).

Progressive and improved regulation could increase the volume and quality of corporate environmental disclosures although there will always be a considerable level of non-compliance (Jiménez et al. 2008). A study of the annual reports of 78 largest Spanish companies between 2001 and 2003 found that there is a significant increase of disclosure after the issuance of Spanish environmental accounting standards (ICAC) in 2002, which obliged companies to provide a more comprehensive disclosure in their annual reports. Interestingly, it was found that the increase of disclosure is comparatively higher, for firms in non-environmentally sensitive industries. Such evidence, to a certain extent provide some indication of the continual existence of reporting as a tool to manage the public impression despite the change of landscape from voluntary to mandatory, as 'comprehensiveness' is very much still related to dilemma in reporting good news rather than bad news, disclosing ritual information and careful selection of information and its reporting media (Jiménez et al. 2008).

An examination on the extent of voluntary carbon emissions disclosure (period 2006 to 2008) during the legislation process of the Australian National Greenhouse and Energy Reporting Act (the NGER Act), provided some evidence as to how environmental regulations enhance the volume and quality of carbon emission disclosures (Choi et al. 2013). Although the abovementioned legislation only started to take effect in year 2009, the percentage of companies providing information on environmental factors were found to increase substantially from $42 \%$ in 2006 to $67 \%$ in 2008 . The visibility factor was found to be important in determining the extent of disclosure. Consistent with legitimacy theory, firms with higher level of carbon emissions and bigger size were found to voluntarily disclose more information. Additionally, the quality of corporate governance was also found to be a key driver for the voluntary disclosures (Choi et al. 2013).

Kuo and Chen (2013) highlighted the role of corporate social responsibilities (CSR) disclosure in improving the environmental performance of Japanese firms. By examining the CSR reporting of 208 
firms listed in the Japan Nikkei Stock Index 500 for the period of 2005-2007, the study found that Japanese firms responded to Kyoto Protocol by seriously considering the issue of environmental management, research and development of energies and ecological information in their CSR reports. In accordance with legitimacy theory, Japanese firms, especially those that are in the environmentally-sensitive industries were found to be more active in using the CSR reports to gain legitimacy.

The impact of the new Chinese Company Law i.e. Guidelines to the State-Owned Enterprises Directly Under the Central Government on Fulfilling Corporate Social Responsibilities (introduced in year 2008), on the volume and quality of corporate social responsibility reporting (between year 2008 to 2010) was found to be more predominant for firms that are centrally controlled, as compared to those that are non-centrally controlled, especially when they are subjected to stock exchange mandate (Zheng et al. 2014). As for the non-centrally controlled firms, the ownership factor seems to be influential in determining the content and comprehensiveness of the disclosure. This is due to the possibility where firms with block ownership could have facilitated shareholders to exercise 'undue influence', thus secure benefits that are detrimental to minority shareholders (Zheng et al. 2014). It is also appealing to note the newly introduced law had also impacted firms which are not mandated to provide Corporate Social Responsibilities information, where it was observed that there was an increase in CSR reporting from 18\% to $28 \%$ (Zheng et al. 2014).

A longitudinal study on environmental reporting by Chelli et al. (2014) found evidence of significant improvement in the quality and quantity of environmental disclosure in the annual reports, environmental reports and web sites of 26 French companies listed in the CAC 40 from year 2001 to 2011. At the year of the 'New Economic Regulation' being enacted, the content analysis results reveal a significant shift from an average environmental score of 9.269 in 2001 to 16.846 in 2002 . Furthermore, during the next 9 years, the average environmental scores were found to keep on improving thus reflecting a continuous and lasting progress in terms of disclosure. The abovementioned findings are expected since companies tend to view legislation as representing what is expected by the institutions thus will response to the institutional pressure by reporting accordingly in order to gain organizational legitimacy (Chelli et al. 2014). This study also found that companies from environmental sensitive industries tend to achieve a higher environmental score. Such findings are consistent with the understanding of legitimacy theory where companies tend to strategically use environmental reporting as a platform to gain legitimacy from the shareholders and society, and such need is more pervasive for companies in the environmental sensitive industries (Chelli et al. 2014).

Environmental disclosure in Indonesia has been studied from various perspectives by a number of researchers. Mirfazli (2008) examined how the high-profile companies and low-profile companies differ in their CSR disclosure. Based on his content analysis on CSR disclosures for the year 2004 of 16 companies listed in Jakarta Stock Exchange (now Indonesian Stock Exchange), He found that there was a significant difference between high-profile and low-profile for disclosure about corporate social responsibility in annual reports. Hidayati's (2011) study also found that different industry have different pattern of undertaking CSR. She said that companies under consumer goods and manufacturing tend to undertake CSR program in both related and unrelated areas to their core business, while company in mining industry tends to do CSR programs which are not related to its core business.In their study of 110 website of Indonesian listed companies in 2008, Djajadikerta and Trireksani (2012) said that the practice of corporate social environmental disclosure in Indonesia is still at an early stage. They viewed that most of the companies still have a lack of understanding about corporate social disclosure and the main reason for their disclosure is to gain societal recognition of the adequacy of their social behavior. However, all of the studies were undertaken prior to the issuance of PP no 47 year 2012. By having this new regulation, it is expected that the participation of Indonesian companies in environmental sustainability activities will increase and their quality of social and environmental reporting will improve.

\section{Research method}

A purposive sampling method was applied to investigate the extent to which the new regulation affects environmental disclosure practices. Based on this method, a set of criteria to select the sample was used: (1) companies listed in Indonesian capital market; (2) categorised under non-financial and services sectors eg. Agriculture; mining; basic industry; miscellaneous; consumer good; property, real estate and 
building construction; and infrastructure, utilities \& transportation; and (3) publishing annual reports in 2011, 2012 and 2013.There were 301 companies listed in Indonesian capital market in 2013 under category of non-financial and services sectors. Among these companies, 249 whose annual reports for 2011, 2012 and 2013 were available in public domain. These 249 companies represent $89.57 \%$ of companies listed in 2011, 87.37\% of those listed in 2012 and $82.72 \%$ of those in 2013.

Approaches for reporting environmental disclosure have been championed by the Global Reporting Initiative (GRI), a non-profit organization that promotes economic sustainability (GRI, 2011). It produces one of the world's most prevalent standards for sustainability reporting also known as ecological footprint reporting, environmental social governance (ESG) reporting, triple bottom line (TBL) reporting, and corporate social responsibility (CSR) reporting (GRI, 2013). GRI seeks to make sustainability reporting by all organizations as routine as, and comparable to, financial reporting (Dragomir, 2009). Information disclosure in this study is categorised under two reporting classifications: Global Reporting Initiative (GRI) and Carbon Emission which is still part of the GRI environmental index, but specifically about carbon emission (EN16, EN 17, EN 18, EN 19 and EN 20). GRI is used as it covers a wide elements of environmental aspects, meanwhile, Carbon Emission is used because the issue of carbon emission had become the government's priority after signing the Kyoto Protocol in 2004.

Table 1 provides summary of variables used to represent the degree of environmental information disclosure. These variables were analysed by using paired sample t-test to see whether there is a significant difference in company disclosure practices before and after the issuance PP 47 year 2012. For all variables, it is hypothesised that there is a significant difference that more information is disclosed after the issuance of the mandatory regulation.

Table 1: Variables used to represent the degree of environmental information disclosure

\begin{tabular}{l|l}
\hline \multicolumn{1}{c|}{ Detailed variable } & \multicolumn{1}{c}{ Measurement } \\
\hline \% of GRI index & $\begin{array}{l}\text { Percentage of index covered by the report to total sum of GRI environmental } \\
\text { reporting index }\end{array}$ \\
\hline GRI number of words & Number of words used to report environmental information based on GRI. \\
\hline $\begin{array}{l}\text { \% of GRI number of words } \\
\text { to total disclosure }\end{array}$ & $\begin{array}{l}\text { Percentage of words used to report environmental information based on GRI as to } \\
\text { the total words in company report. }\end{array}$ \\
\hline \% CE index & Percentage ofCE related index covered by the report to total sum of CE related index \\
\hline CE number of words & $\begin{array}{l}\text { Number of words used to report environmental information based on Carbon } \\
\text { Emission. }\end{array}$ \\
\hline
\end{tabular}

Additional analysis was undertaken to see in which types of company the new regulation worked better in making improvement on environmental disclosures. This was based on previous studies which found that types of ownership (private or government ownership) (Zheng et al, 2014) and types of industry had different degree in responding to the mandatory disclosure policy (Choi et al., 2013).

The classification of type of industry in this study refer to the IPCC (2007) report on greenhouse gas emission based on industrial sector. The report shows a wide range of carbon emission contributed by industrial sectors. Most studies in environmental dislosure classified companies under two categories of high-profile and low-profile companies (Hackston and Milne, 1996; and Mirfazli, 2008) or sensitive and less-sensitive (Kuo and Chen, 2013; Jiménezet al, 2008; Dragomir, 2010; and Choi et al., 2013). According to authors, based on the data produced by the IPCC, the two categorical classification is too simplistic in looking at the industrial category. Thus, in this study, three-categorical carbon emission classification was used: high, moderate, and low. In the IPCC's (2007) report, energy supply shared $25.9 \%$ carbon emission and it is the only industrial sector with more than $20 \%$ carbon emission. In this research, this sector refers to the mining sector of Indonesia Stock Exchange and is categorised as 'high carbon emission'. The moderate carbon emission classification is based on sectors whose carbon emission contribute between 10$20 \%$. These sectors are industry, forestry, agriculture and transportation. In Indonesia stock exchange, these sectors refer to agriculture, basic industry and chemicals, miscellaneous, consumer goods, and infrastructure, utilities \& transportation. Finally, the low carbon emission is resident and commercial building and waste and wastewater sectors whose carbon emission contribute below $10 \%$. In this study these sectors refer to property, real estate and building construction. 
Figure 1: Carbon Emission (CE) classification based on Industrial Sector

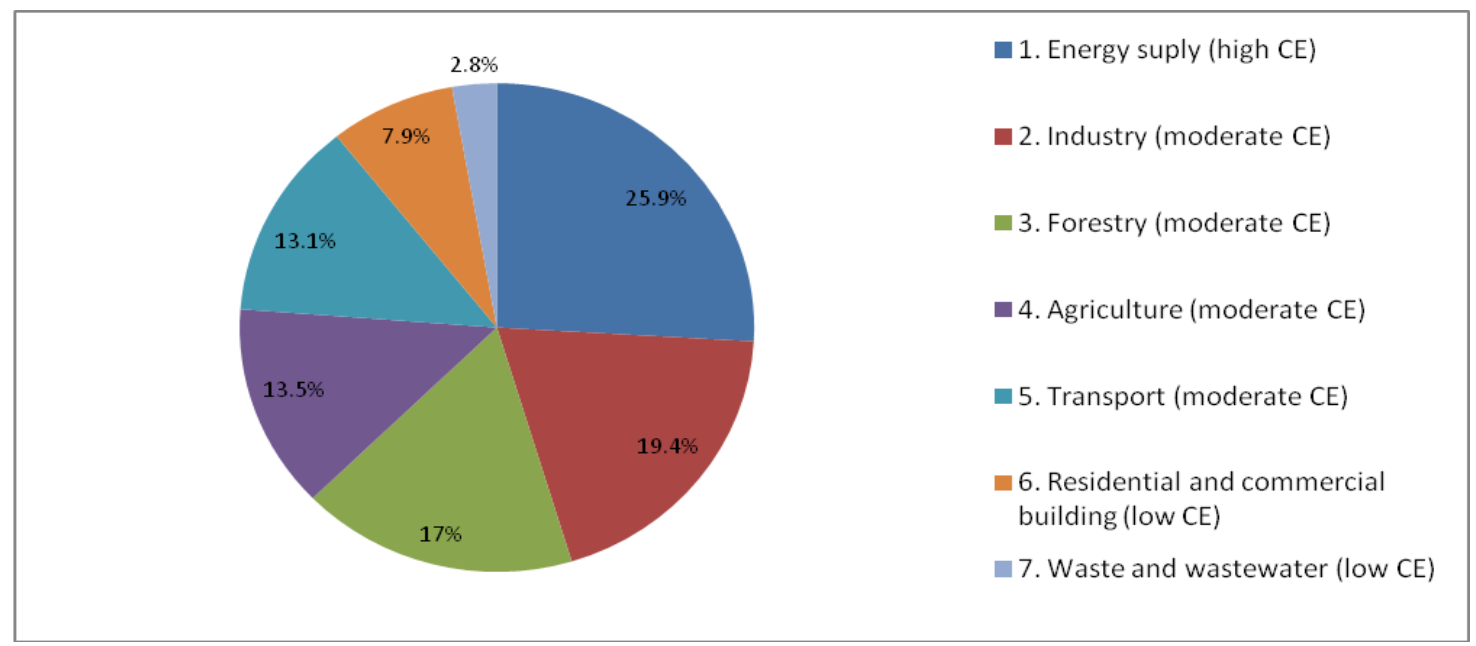

Source: IPCC, 2007 with addition onto the three CE classification by theAuthors

\section{Findings}

Table 2 shows the percentage of companies disclosing based on GRI during 2011-2013. In 2011, there were only $13.95 \%$ of companies of the population. The figure increase to become $25.25 \%$ in 2012 and $30.90 \%$ in 2013. In terms of industrial sector, prior to the issuance of PP $47 / 2012$, mining sector was the largest in proportion of companies reporting based on GRI (38.49\%) compared to total companies in the same industry. However, when the regulation was issued, it was the agriculture sector as the largest proportion (47.37\% in 2012 and $52.63 \%$ in 2013).

Table 2: Percentage of companies disclosing based on GRI

from 2011 to 2013

\begin{tabular}{|c|c|c|c|c|c|c|c|c|}
\hline No & Sector & $\begin{array}{c}\text { Total } \\
\text { population }\end{array}$ & $\begin{array}{c}\text { Number of } \\
\text { companies } \\
\text { disclosing GRI } \\
2011\end{array}$ & $\begin{array}{c}\text { \% of } \\
\text { companies } \\
\text { disclosing } \\
\text { GRI } 2011\end{array}$ & $\begin{array}{c}\text { Number of } \\
\text { companies } \\
\text { disclosing } \\
\text { GRI } 2012\end{array}$ & $\begin{array}{c}\text { \% of } \\
\text { companies } \\
\text { disclosing } \\
\text { GRI } 2012\end{array}$ & $\begin{array}{c}\text { Number of } \\
\text { companies } \\
\text { disclosing } \\
\text { GRI } 2013\end{array}$ & $\begin{array}{c}\% \text { of } \\
\text { companies } \\
\text { disclosing } \\
\text { GRI } 2013\end{array}$ \\
\hline 1 & Agriculture & 19 & 7 & $36.84 \%$ & 9 & $47.37 \%$ & 10 & $52.63 \%$ \\
\hline 2 & Mining & 39 & 15 & $38.46 \%$ & 15 & $38.46 \%$ & 19 & $48.72 \%$ \\
\hline 3 & $\begin{array}{l}\text { Basic Industry } \\
\text { and chemicals }\end{array}$ & 63 & 12 & $19.05 \%$ & 15 & $23.81 \%$ & 17 & $26.98 \%$ \\
\hline 4 & Miscellaneous & 41 & 2 & $4.88 \%$ & 3 & $7.32 \%$ & 3 & $7.32 \%$ \\
\hline 5 & $\begin{array}{l}\text { Consumer } \\
\text { Goods }\end{array}$ & 37 & 1 & $2.70 \%$ & 2 & $5.41 \%$ & 12 & $32.43 \%$ \\
\hline 6 & $\begin{array}{l}\text { Property, Real } \\
\text { Estate and } \\
\text { Building } \\
\text { Construction }\end{array}$ & 55 & 4 & $7.27 \%$ & 20 & $36.36 \%$ & 20 & $36.36 \%$ \\
\hline 7 & $\begin{array}{l}\text { Infrastructure, } \\
\text { Utilities \& } \\
\text { Transportation }\end{array}$ & 47 & 1 & $2.13 \%$ & 12 & $25,53 \%$ & 12 & $25,53 \%$ \\
\hline & TOTAL & 301 & 42 & $13.95 \%$ & 76 & $25,25 \%$ & 93 & $30,90 \%$ \\
\hline
\end{tabular}

In terms of carbon emission reporting, there was a steady increase from 9.63\% \% in 2011, 11.96 in 2012 and $15.61 \%$ in 2013. These lower figure compared to GRI, is because some companies in all industries tend not to report carbon emission aspects, although they have started to report other GRI environmental aspects. Quite similar to GRI based reporting, mining sector was the highest proportion in reporting carbon emission in 2011, and agriculture sector in 2012 and 2013. 
Table 2: Percentage of companies disclosing CE from 2011 to 2013

\begin{tabular}{|l|l|c|c|c|c|c|c|c|}
\hline No & \multicolumn{1}{|c|}{ Sector } & $\begin{array}{c}\text { Total } \\
\text { population }\end{array}$ & $\begin{array}{c}\text { Number of } \\
\text { companies } \\
\text { disclosing } \\
\text { CE 2011 }\end{array}$ & $\begin{array}{c}\% \text { of } \\
\text { companies } \\
\text { disclosing CE } \\
2011\end{array}$ & $\begin{array}{c}\text { Number of } \\
\text { companies } \\
\text { disclosing } \\
\text { CE 2012 }\end{array}$ & $\begin{array}{c}\text { \% of } \\
\text { companies } \\
\text { disclosing } \\
\text { CE 2012 }\end{array}$ & $\begin{array}{c}\text { Number } \\
\text { of } \\
\text { companies } \\
\text { disclosing } \\
\text { CE 2013 }\end{array}$ & $\begin{array}{c}\% \text { of } \\
\text { companies } \\
\text { disclosing } \\
\text { CE 2013 }\end{array}$ \\
\hline 1 & Agriculture & 19 & 4 & $21.05 \%$ & 4 & $21.05 \%$ & 6 & $31.58 \%$ \\
\hline 2 & Mining & 39 & 10 & $25.64 \%$ & 8 & $20.51 \%$ & 12 & $30.77 \%$ \\
\hline 3 & Basic Industry & 63 & 8 & $12.70 \%$ & 7 & $11.11 \%$ & 13 & $20.63 \%$ \\
\hline 5 & Miscellaneous & 41 & 0 & $0.00 \%$ & 2 & $4.88 \%$ & 1 & $2.44 \%$ \\
\hline 6 & $\begin{array}{l}\text { Consumer Goods } \\
\text { Estate and } \\
\text { Building } \\
\text { Construction }\end{array}$ & 37 & 1 & $2.70 \%$ & 1 & $2.70 \%$ & 3 & $8.11 \%$ \\
\hline 7 & $\begin{array}{l}\text { Infrastructure, } \\
\text { Utilities \& } \\
\text { Transportation }\end{array}$ & 47 & 1 & $1.82 \%$ & 8 & $14.55 \%$ & 5 & $9.09 \%$ \\
\hline & \multicolumn{1}{|l|}{ TOTAL } & 301 & 29 & $9.63 \%$ & 36 & $11.96 \%$ & 47 & $15.61 \%$ \\
\hline
\end{tabular}

Comparative analysis of this study is based on 249 companies whose annual reports were available to the public since 2011 to 2013. In addition, sustainability reports published by the companies were also included in the analysis. Table 3 shows that onlysmall amount of companies which published sustainability reports. However, the number of companies publishing it increased slighly from 13 companies to 15 in 2012 and 17 in 2013 . Within the three years, companies publishing sustainability reports are dominated by mining and infrastructure companies.

Table 3: Companies publishing sustainability reports from 2011 to 2013

\begin{tabular}{|c|c|c|c|c|c|}
\hline No & Sector & $\begin{array}{l}\text { Number of companies } \\
\text { in the sample analysis }\end{array}$ & $\begin{array}{c}\text { Sustainability } \\
\text { Reports } \\
2011 \\
\end{array}$ & $\begin{array}{c}\text { Sustainability } \\
\text { Reports } \\
2012 \\
\end{array}$ & $\begin{array}{c}\text { Sustainability } \\
\text { Reports } \\
2013 \\
\end{array}$ \\
\hline 1 & Agriculture & 14 & 2 & 2 & 2 \\
\hline 2 & Mining & 36 & 5 & 5 & 6 \\
\hline 3 & Basic Industry & 54 & 2 & 3 & 3 \\
\hline 4 & Miscellaneous & 35 & 1 & 1 & 1 \\
\hline 5 & Consumer Goods & 28 & 0 & 0 & 0 \\
\hline 6 & $\begin{array}{l}\text { Property, Real Estate and } \\
\text { Building Construction }\end{array}$ & 47 & 0 & 0 & 1 \\
\hline \multirow[t]{2}{*}{7} & $\begin{array}{l}\text { Infrastructure, Utilities \& } \\
\text { Transportation }\end{array}$ & 35 & 3 & 4 & 4 \\
\hline & TOTAL & 249 & 13 & 15 & 17 \\
\hline
\end{tabular}

These 249 companies were classified further based on their type of ownerships and characteristics of carbon emission. Among the 249 companies, sixteen companies were classified as state owned companies and 233 were private. Based on their characteristics of carbon emission, 47 companies were classified as low carbon emission, 166 as moderate carbon emission and 36 ashigh carbon emission.

Table 4 shows mean for level of disclosures for the whole 249 samples and with detailed analysis based on their types of ownership. Looking at their means which are higher than the average for the whole sample, companies owned by the government have higher mean than private companies. This indicates that the government owned companies practice more environmental disclosures than the private companies both before and after the mandatory disclosure policy. However, for the government 
company, compared to the year before the regulation was issued, the increment in 2012 went down in 2013 in all aspects of measurement indicators. On the other hand, for private companies the increase in 2013 in higher than in 2012, indicating greater efforts were given to disclose environmental disclosure after the regulation was issued.

Table 4: Mean of environmental disclosure 2011 -2013 based on type of ownership

\begin{tabular}{|c|c|c|c|c|c|c|c|}
\hline \multirow[b]{2}{*}{$\begin{array}{l}\text { Indicators for } \\
\text { level of disclosure }\end{array}$} & \multirow[b]{2}{*}{ Year } & \multicolumn{2}{|c|}{$\begin{array}{c}\text { All } 249 \text { companies in the } \\
\text { sample }\end{array}$} & \multicolumn{2}{|c|}{16 Owned by Government } & \multicolumn{2}{|c|}{233 Owned by Private } \\
\hline & & Mean & $\begin{array}{l}\text { Increment } \\
\text { compared to } \\
\text { year } 2011\end{array}$ & Mean & $\begin{array}{c}\text { Increment } \\
\text { compared to } \\
\text { year } 2011\end{array}$ & Mean & $\begin{array}{c}\text { Increment } \\
\text { compared to } \\
\text { year } 2011\end{array}$ \\
\hline \multirow{3}{*}{$\%$ of GRI index } & 2011 & 4.39 & na & 22.27 & na & 3.16 & na \\
\hline & 2012 & 6.77 & $54.21 \%$ & 41.56 & $86.62 \%$ & 4.38 & $38.61 \%$ \\
\hline & 2013 & 6.42 & $46.24 \%$ & 25.54 & $14.68 \%$ & 5.11 & $61.71 \%$ \\
\hline \multirow{3}{*}{$\begin{array}{l}\text { GRI number of } \\
\text { words }\end{array}$} & 2011 & 138.94 & na & 807.19 & na & 93.06 & na \\
\hline & 2012 & 220.45 & $58.67 \%$ & $1,357.69$ & $68.20 \%$ & 142.36 & $52.98 \%$ \\
\hline & 2013 & 214.28 & $54.22 \%$ & 903.38 & $11.92 \%$ & 166.96 & 79.41\% \\
\hline \multirow{3}{*}{$\begin{array}{c}\% \text { of GRI number } \\
\text { of words to total } \\
\text { disclosure }\end{array}$} & 2011 & 0.39 & na & 0.91 & na & 0.35 & na \\
\hline & 2012 & 0.51 & $30.77 \%$ & 1.68 & $84.62 \%$ & 0.43 & $22.86 \%$ \\
\hline & 2013 & 0.58 & $48.72 \%$ & 1.03 & $13.19 \%$ & 0.55 & $57.14 \%$ \\
\hline \multirow{3}{*}{$\%$ of CE index } & 2011 & 5.3 & na & 27.5 & na & 3.78 & na \\
\hline & 2012 & 6.91 & $30.38 \%$ & 47.5 & $72.73 \%$ & 4.12 & $8.99 \%$ \\
\hline & 2013 & 6.51 & $22.83 \%$ & 30 & $9.09 \%$ & 4.89 & $29.37 \%$ \\
\hline \multirow{3}{*}{$\begin{array}{l}\text { CE number of } \\
\text { words }\end{array}$} & 2011 & 20.75 & na & 138.56 & na & 12.66 & na \\
\hline & 2012 & 35.02 & $68.77 \%$ & 248 & $78.98 \%$ & 20.4 & $61.14 \%$ \\
\hline & 2013 & 28.96 & $39.57 \%$ & 132.75 & $-4.19 \%$ & 21.83 & $72.43 \%$ \\
\hline
\end{tabular}

Table 5 shows mean for level of disclosures for companies based on their carbon emission characteristics. Companies with high carbon emission report much greater environmental aspects than those under moderate and low category, indicating that these companies had anticipated the environmental reporting regulation better than the other two categories of companies. This shows that the practices of environmental reporting in Indonesia is still similar to Mirfazli's (2008) study that companies that are more enviromentally sensitive disclosed more than companies that are less environmentally sensitive.

Table 5: Mean of environmental disclosure 2011 - 2013 based on Carbon Emission Characteristics

\begin{tabular}{|c|c|c|c|c|c|c|c|}
\hline \multirow{2}{*}{$\begin{array}{c}\text { Indicators for } \\
\text { level of } \\
\text { disclosure }\end{array}$} & \multirow{2}{*}{ Year } & \multicolumn{2}{|c|}{$\begin{array}{l}47 \text { companies under industry } \\
\text { with low carbon emission }\end{array}$} & \multicolumn{2}{|c|}{$\begin{array}{l}166 \text { companies under } \\
\text { industry with moderate } \\
\text { carbon emission }\end{array}$} & \multicolumn{2}{|c|}{$\begin{array}{c}36 \text { companies under } \\
\text { industry with high carbon } \\
\text { emission }\end{array}$} \\
\hline & & Mean & $\begin{array}{l}\text { Increment } \\
\text { compared to } \\
\text { year } 2011\end{array}$ & Mean & $\begin{array}{l}\text { Increment } \\
\text { compared to } \\
\text { year } 2011\end{array}$ & Mean & $\begin{array}{c}\text { Increment } \\
\text { compared to } \\
\text { year } 2011\end{array}$ \\
\hline \multirow{3}{*}{$\%$ of GRI index } & 2011 & 0.57 & na & 3.01 & na & 15.72 & na \\
\hline & 2012 & 1.77 & $210.53 \%$ & 5.99 & $99.00 \%$ & 16.89 & $7.44 \%$ \\
\hline & 2013 & 2.06 & $261.40 \%$ & 5.23 & $73.75 \%$ & 17.64 & $12.21 \%$ \\
\hline \multirow{3}{*}{$\begin{array}{c}\text { GRI number of } \\
\text { words }\end{array}$} & 2011 & 14.83 & na & 83.82 & na & 555.17 & na \\
\hline & 2012 & 46.96 & $216.66 \%$ & 172.67 & $106.00 \%$ & 667.28 & $20.19 \%$ \\
\hline & 2013 & $52 . .81$ & $256.10 \%$ & $167 . .96$ & $100 . .38 \%$ & $638 . .69$ & $15 . .04 \%$ \\
\hline \multirow{3}{*}{$\begin{array}{c}\% \text { of GRI } \\
\text { number of } \\
\text { words to total } \\
\text { disclosure }\end{array}$} & 2011 & 0.14 & na & 0.33 & na & 0.98 & na \\
\hline & 2012 & 0.3 & $114.29 \%$ & 0.47 & $42.42 \%$ & 0.98 & $0.00 \%$ \\
\hline & 2013 & 0.26 & $85.71 \%$ & 0.56 & $69.70 \%$ & 1.07 & $9.18 \%$ \\
\hline \multirow{3}{*}{$\%$ of CE index } & 2011 & 0.43 & na & 4.34 & na & 16.11 & na \\
\hline & 2012 & 2.98 & $593.02 \%$ & 5.78 & $33.18 \%$ & 17.22 & $6.89 \%$ \\
\hline & 2013 & 2.13 & $395.35 \%$ & 5.78 & $33.18 \%$ & 15.56 & $-3.41 \%$ \\
\hline \multirow{3}{*}{$\begin{array}{l}\text { CE number of } \\
\text { words }\end{array}$} & 2011 & 1.15 & na & 16.14 & na & 67.61 & na \\
\hline & 2012 & 13.47 & $1071.30 \%$ & 28.96 & $79.43 \%$ & 91.14 & $34.80 \%$ \\
\hline & 2013 & 10.45 & $808.70 \%$ & 24.93 & $54.46 \%$ & 71.67 & $6.01 \%$ \\
\hline
\end{tabular}


Table 5 also shows that environmental disclosures increased in most indicators in 2012 compared to the year before the mandatory regulation was issued. However, the level of increased practice of environmental disclosure in 2012 was not followed consistently by the increase practice in 2013. Companies under high carbon emission were declining in all indicators from 2012 to 2013 except for percentage of GRI based index. On the other hand, companies with low carbon emission, continued their increase in \% of GRI based index and the GRI based number of words. This finding is consistent with Jiménezet al's (2008) investigation in Spain, that less sensitive companies were found to increase comparatively higher than those in more environmentally-sensitive companies when a mandatory disclosure policy is issued.

Table 6 shows the result of paired sample t-test to see whether the increase of the environmental disclosure practices is significant statistically. The practices in 2012 and 2013 as compared to the practices in 2011 are significant in a number of variables. For the whole 249 samples, three variables (\% of GRI index, GRI number of words and CE number of words) increased significantly when the practices were compared to the year in 2012 and 2013. One variable (\% of GRI number of words) only increased significantly when they were compared to the practices in 2013 but not significant with 2012. The other variable (\% CE index) has no significant different when it was compared to the practices in both 2012 and 2013. This indicates that increased practices of environmental disclosure based on GRI can be expected immediately and to some extent continued in the following year. However, for carbon emission practices, significant increase can be expected in the year the policy is issued, but then the increase drops in the following year.

Table 6: Paired sample t-test for level of environmental disclosure 2011-2012 and 2011-2013

\begin{tabular}{|c|c|c|c|c|c|c|}
\hline $\begin{array}{c}\text { Indicators for level of } \\
\text { disclosure }\end{array}$ & $\begin{array}{l}\text { Sig. (2-tailed) } \\
\text { For } 249 \\
\text { companies } \\
\text { disclosing } \\
\text { environmental } \\
\text { report }\end{array}$ & $\begin{array}{c}\text { Sig. (2-tailed) } \\
\text { for } 16 \\
\text { companies } \\
\text { owned by } \\
\text { Indonesian } \\
\text { Government }\end{array}$ & $\begin{array}{l}\text { Sig. (2- } \\
\text { tailed) } \\
\text { For } 233 \\
\text { companies } \\
\text { owned by } \\
\text { private } \\
\text { sector }\end{array}$ & $\begin{array}{c}\text { Sig. (2-tailed) } \\
\text { for } 47 \\
\text { companies } \\
\text { under } \\
\text { industries } \\
\text { with low } \\
\text { carbon } \\
\text { emission } \\
\end{array}$ & $\begin{array}{l}\text { Sig. (2-tailed) } \\
\text { for } 166 \\
\text { companies } \\
\text { under } \\
\text { industries with } \\
\text { moderatecarbon } \\
\text { emission }\end{array}$ & $\begin{array}{c}\text { Sig. (2-tailed) } \\
36 \text { for } \\
\text { companies } \\
\text { under } \\
\text { industries } \\
\text { with } \\
\text { highcarbon } \\
\text { emission } \\
\end{array}$ \\
\hline $\begin{array}{l}\text { \% of GRI index } 2011 \text { - } \\
2012\end{array}$ & $0.009^{* * *}$ & $0.036^{* *}$ & $0.093^{*}$ & $0.033^{* *}$ & $0.017^{* *}$ & 0.627 \\
\hline $\begin{array}{l}\text { \% of GRI index } 2011 \text { - } \\
2013\end{array}$ & $0.000^{* * *}$ & 0.167 & $0.000^{* * *}$ & $0.026^{* *}$ & $0.001^{* * *}$ & 0.360 \\
\hline $\begin{array}{l}\text { GRI number of words } \\
\text { (NOW) 2011-2012 }\end{array}$ & $0.017^{* *}$ & 0.064 & 0.103 & $0.038^{* *}$ & $0.034^{* *}$ & 0.411 \\
\hline $\begin{array}{l}\text { GRI number of words } \\
2011-2013\end{array}$ & $0.011^{* *}$ & 0.479 & $0.014^{* *}$ & $0.043^{* *}$ & $0.001^{* * *}$ & 0.617 \\
\hline $\begin{array}{l}\% \text { of GRI number of } \\
\text { words to total disclosure } \\
2011-2012\end{array}$ & 0.111 & 0.119 & 0.293 & 0.185 & 0.181 & 0.990 \\
\hline $\begin{array}{l}\% \text { of GRI number of } \\
\text { words to total disclosure } \\
2011-2013\end{array}$ & $0.008^{* * *}$ & 0.516 & $0.009^{* * *}$ & 0.343 & $0.004^{* * *}$ & 0.759 \\
\hline$\%$ of CE index 2011-2012 & 0.116 & $0.045^{\text {** }}$ & 0.684 & $0.032^{* *}$ & 0.294 & 0.689 \\
\hline$\%$ of CE index 2011-2012 & 0.147 & 0.544 & 0.187 & 0.160 & 0.128 & 0.872 \\
\hline $\begin{array}{l}\text { CE number of words } \\
2011-2012\end{array}$ & $0.021^{* *}$ & 0.114 & $0.097^{*}$ & $0.044^{*}$ & $0.088^{*}$ & 0.338 \\
\hline $\begin{array}{l}\text { CE number of words } \\
2011-2013\end{array}$ & $0.054^{*}$ & 0.706 & $0.039^{* *}$ & 0.103 & $0.039^{* *}$ & 0.848 \\
\hline
\end{tabular}

Detail analysis shows interesting finding that the mandatory policy does not have significant effect to the companies under industries with high carbon emission ie. mining. This finding is not consistent to Choi et al's (2013) study in Australia that larger firms with higher visibility tend to disclose more comprehensive information after the issuance of the mandatory policy. On the other hand, significant increases occured in a number of variables for companies under industry with low and moderate carbon emission. This finding is consistent to what happened in Spain where less sensitive companies increase in reporting is higher than those that are more environmentally sensitive (Jiménez et 
al, 2008). This study also supports Zheng et al.'s (2014) finding that firms that are not mandated to provide CSR information, had increased percentage in reporting CSR which is above average for all companies. This condition can be explained by development of regulation in Indonesia that prior to this mandatory policy, Indonesia government had already put in place environmental regulation for companies under mining industry. Therefore, companies under this industry could have already given their efforts to show the public what they have done for environmental sustainability. This phenomenon indicates that the mandatory policy is more relevant for companies which were not regulated before as they are now more aware of their accountability to report on their environmental activities.

\section{Discussion and conclusion}

The findings of this study highlight some interesting insights concerning the compliance of the recently introduced governmental regulation on social and environmental responsibilities among companies listed in the Indonesian capital market. Formally, PP 47/2012 is an answer to academics expectation for follow up of Company Act which require companies to undertake corporate social responsibility. However, doubts was addressed to this regulation as to (1) no sanction was stated for the companies which do not disclose their social or environmental matters; and (2) no standards were introduced on how to report companies environmental issues.

This study shows that the effect of PP 47/2012 had taken place immediately in the year it was issued. Based on the analysis of annual reports of 249 companies listed in Indonesia stock exchange, there were significant increases in a number of measurement indicators (percentage of GRI index being reported, number of words used to report GRI environmental issues, percentage of carbon emission index being reported and number of words used to report carbon emission aspects) in the year the policy being issued. Other variable (percentage of GRI number of words to total disclosure) increased significantly a year after the issuance of the mandatory policy.The newly introduced regulation had changed the landscape of environmental disclosure in Indonesia as the percentage of companies that conducted environmental disclosures had increased from 13.95\% (year 2011) to 25.25\% (year 2012), followed by $30.9 \%$ (year 2013). Hence, this study supports legitimacy dynamics of Suchman (1995) that legitimacy would consider social audience, whereby in this case is the regulator with new regulation, that the company will have to match the new expectations by disclosing more information to remain legitimate (Suchman, 1995).

The newly introduced regulation had spurred the need for the less environmental sensitive companies to obtain legitimacy through environmental disclosure. This is evidence from the research findings where environmental related disclosures were found to increase significantly for the less environmental sensitive companies (agriculture; property, real estate and building construction; infrastructure, utilities and transportation) in terms of GRI percentage right after the introduction of the new regulation in 2012. This confirms the need to recognise legitimation phases of a company as proposed by Suchman (1995). Companies which is at the position of maintaining their legitimacy tend to act at status quo protecting past accomplishments. This can be seen at companies with high carbon emission ie mining companies which have been previously regulated in terms of environmental obligation and had efforts earlier in environmental reporting. Thus, when the mandatory disclosure policy was issued, they did not make significant changes. On the other hand, companies with moderate and low carbon emission which was not really aware of the environmental reporting, was proven to give more efforts after the mandatory policy was issued, in order to gain legitimacy in this matter.

This suggests that there is a need to provide a detail guideline for companies on what to report by addressing different characteristics of each industrial sectors in order to provide the public with adequate and relevant information. In this case what was done in Spain through revising and detailing their mandatory policy can be considered (Jiménezet. al. 2008). The other way for policy makers to increase the effectiveness of this new regulation is by clearly indicating the penalty for non-compliance hence providing the coercive pressure for companies to improve on environmental reporting (Chelli et al. 2014).

\section{Conclusion, limitations and suggestions for future research}

This study is a first attempt to categorise companies listed in the Indonesian stock exchange based on their environmental sensitivity, according to their carbon emission. This study supports legitimacy 
theory of disclosures where public expectations on companies change through the issuance of mandatory policy to perform and to disclose its environmental responsibility, the company will take it into consideration by disclosing more information to remain legitimate. The effect of PP 47/2012 had taken place immediately in the year it was issued. Based on the analysis of annual reports of 249 companies listed in Indonesia stock exchange, there were significant increases for variables percentage of GRI index being reported, number of words used to report GRI environmental issues, percentage of carbon emission index being reported and number of words used to report carbon emission aspects.

Other variable such as percentage of GRI number of words to total disclosure increased significantly a year after the issuance of the mandatory policy. Based on detail analysis, it is found that significant increases occur not among the companies with high carbon emission, but among the companies with moderate or low carbon emission. This study has limited scope which only make comparison with the year of issuance and one year after the issuance. In the future, a longer period of analysis will be able to uncover on the consistency of the regulation in promoting better practices of companies environmental reporting when responding to the mandatory policy.

\section{Acknowledgement}

Authors are indebted to the Directorate of Higher Learning, Ministry of Higher Learning, Research and Technology, Republic of Indonesia, which has provided fund for this research under Competitive Grant (Hibah Bersaing) scheme 2014/15. As sponsor, the Ministry has no intervention on the design, processes and analysis of this research.

\section{References}

Ashforth, B. E. and Gibbs, B. W. (1990), “The double-edge of organisational legitimation”. Organization Science, Vol I, No. 2, pp. 177-94.

PricewaterhouseCoopers (2013) Sector insights: what is driving climate change action in the world's largest companies? Global 500 Climate Change Report 2013, Carbon Disclosure Project, retrieved 11 September 2015.

https://www.cdp.net/CDPResults/CDP-Global-500-Climate-Change-Report-2013.pdf.

Chelli, M., Durocher, S. and Richard, J. (2014), "France's new economic regulations: insights from institutional legitimacy theory", Accounting, Auditing \& Accountability Journal, Vol. 27 No. 2, pp. 283-316.

Choi B., Lee D. and Psaros J. (2013), "An analysis of Australian company carbon emission disclosure". Pasific Accounting review, Vol 25 No. 1, pp. 58-79.

Clarkson, P., Li, Y., Richardson, G., Vasivari, F. (2008), "Revisiting the relation between environmental performance and environmental disclosure: an empirical analysis", Accounting, Organizations, and Society, Vol. 33 No. 4-5, pp. 303-327.

Deegan, C and Rankin, M. (1996), “Do Australian companies report environmental news objectively?: An analysis of environmental disclosures by firms prosecuted successfully by the Environmental Protection Authority", Accounting, Auditing \& Accountability Journal, Vol. 9 No. 1, pp. 50-67.

Deegan, C. (2002), "The legitimising effect of social and environmental disclosures: a theoretical foundation", Accounting, Auditing \& Accountability Journal, Vol. 15 No. 3, pp. 282-311.

Djajadikerta G.H., and Trireksani T. (2012), Corporate social and environmental disclosure by indonesian listed companies on their corporate web sites. Journal of Applied Accounting Research, Vol. 13 No. 1, pp. 21-26.

Dragomir VD., (2010), "Environmental sensitive disclosure and financial performance in a European setting", Journal of Accounting and Organization Change, Vol. 6 No. 3, pp 359-388.

Global Reporting Initiative (2011). Sustainability reporting guidelines version 3.1. World commissions on environment development our common future. Oxford; Oxford University Press. United Kingdom.

Global Reporting Initiative (2013). Maps of Global Industry Clasification Standard (GICS) to proposed GRI Business Activity Groups. URL:

http://www.globalreporting.org/reporting/sector-guidance/topic research/pages/defoult.aspx. Accessed: 06 Jan 2014.

Gray, R., Kouhy, R. and Lavers, S. (1995), “Corporate social and environmental reporting”, Accounting, Auditing $\mathcal{E}$ Accountability Journal, Vol. 8 No. 2, pp. 47-77.

Guthrie, J. and Parker, L.D. (1989), "Corporate social reporting: a rebuttal of legitimacy theory", Accounting \& Business Research, Vol. 9 No. 76, pp. 343-352.

Hackston, D. and Milne, M.J. (1996), "Some determinants of social and environmental disclosures in New Zealand companies", Accounting, Auditing \& Accountability Journal, Vol. 9 No. 1, pp. 77-108.

Hidayati, N.D. (2011), "Pattern of corporate social responsibility programs: a case study", Social Responsibility Journal, Vol. 7 No. 1, pp. 104-17. 
IPCC, (2007), Climate Change 2007: Mitigation. Contribution of Working Group III to the Fourth Assessment Report of the Inter-governmental Panel on Climate Change [B. Metz, O.R. Davidson, P.R. Bosch, R. Dave, L.A. Meyer (eds)], Cambridge University Press, Cambridge, United Kingdom and New York, NY, USA.

Jiménez, I. C., Chulián, M. F., Carqués, F. J. H. and González, C. L. (2008), “Compliance with Mandatory Environmental Reporting in Financial Statements: The Case of Spain (2001-2003)", Journal of Business Ethics, Vol. 79, No. 3, pp. 245-262.

Kuo, L. and Chen, V. Y. (2013), “Is environmental disclosure an effective strategy on establishment of environmental legitimacy for organization?" Management Decision Vol. 51, No. 7, pp. 1462-1487.

Lindblom, C.K. (1993), "The implications of organizational legitimacy for corporate social performance and disclosure", Paper presented at the Critical Perspectives on Accounting Conference, New York.

Mathews, M.R. (1993), Socially Responsible Accounting. Chapman \& Hall, London.

Meyer, J. W. \& Rowan, B. (1991). Institutionalized organizations: Formal structure as myth and ceremony. In W.W. Powell \& P. J. DiMaggio (Eds.), the new institutionalism in organizational analysis (pp. 41-62). Chicago: University of Chicago Press.

Mirfazli, E., (2008), "Evaluate corporate social responsibility disclosure at Annual Report Companies in multifarious group of industry members of Jakarta Stock Exchange (JSX), Indonesia", Social Responsibility Journal, Vol. 4 No. 3, pp. 388-406.

Mobus, J. L. (2005), "Mandatory environmental disclosures in a legitimacy theory context", Accounting, Auditing $\mathcal{E}$ Accountability Journal, Vol. 18 No.4, pp. 492-517.

Newton, T. and Harte, G. (1997): “Green Business: Technicist Kitsch?” Journal of Management Studies, Vol. 34, No. 1, pp. 75-98.

Nik Nazli, N. A and Sulaiman, M. (2004), "Environment disclosure in Malaysia annual reports: a legitimacy theory perspective", International Journal of Commerce and Management, Vol. 14 No. 1, 2004

Suchman, M. C. (1995), "Managing legitimacy: strategic and institutional approaches", Academy of Management Review, Vol. 20 No. 3, pp. 571-610.

Tilt, C. A. (1994), "The influence of external pressure groups on corporate social disclosure: some empirical evidence”, Accounting, Auditing \& Accountability Journal, Vol. 7 No. 4, pp 47-72.

Utama, S. (2011), "An evaluation of support infrastructures for corporate responsibility reporting in Indonesia", Asian Busines s E Management, Vol. 10 No. 3, pp. 405-424.

Zheng, L., Balsara, N. and Huang, H. (2014), "Regulatory pressure, blockholders and corporate social responsibility (CSR) disclosures in China", Social Responsibility Journal, Vol. 10 No. 2, pp. 226-245. 